\title{
Conservative fluid therapy in septic shock: an example of targeted therapeutic minimization
}

\author{
Catherine Chen and Marin H Kollef
}

\begin{abstract}
Intravenous fluids (IVFs) represent a basic therapeutic intervention utilized in septic shock. Unfortunately, the optimal method for administering IVFs to maximize patient outcomes is unknown. A meta-analysis of four randomized trials of goal-directed therapy did not demonstrate a significant reduction in mortality (odds ratio 0.609; 95\% confidence interval 0.363 to 1.020; $P=0.059$ ), whereas 18 trials with historical controls showed a significant increase in survival (odds ratio 0.580; 95\% confidence interval 0.501 to $0.672 ; P<0.0001)$. Based on these data, clinicians should be aware of the potential for harm due to the excessive administration of IVFs to patients with septic shock.
\end{abstract}

\section{Introduction}

Intravenous fluids (IVFs) are one of the most common therapies provided to critically ill patients. IVF administration is largely empiric, although goal-directed approaches have been used in an attempt to optimize resuscitation in unstable patients [1,2]. Excessive use of any therapeutic agent can be associated with potential harm; excessive use of antibiotics [3,4], sedation [5,6], tidal volume $[7,8]$, transfusions [9], and glucose [10] have all been linked to unfavorable patient outcomes. It is now recognized that excessive IVFs may also contribute to new complications and worsening of underlying disease processes, including acute respiratory distress syndrome, abdominal compartment syndrome, coagulopathy, and cerebral edema [11-14]. Unfortunately, a systematic approach for delivery of IVFs in critically ill patients does not exist. This is partly related to the various conditions managed in the ICU setting, as well as the varied approaches to IVF administration and availability of different IVF types (that is,

\footnotetext{
*Correspondence: mkollef@dom.wustl.edu

Division of Pulmonary and Critical Care Medicine, Washington University School of Medicine, 660 South Euclid Avenue, St Louis, MO 63110, USA
}

colloids, and balanced and unbalanced crystalloids). Goal-directed therapy (GDT) for IVF administration in the first 6 hours of septic shock is now advocated by the most recent version of the Surviving Sepsis Campaign guidelines with a $1 \mathrm{C}$ evidence recommendation [1]. However, not all clinicians and investigators are convinced that this approach is optimal $[15,16]$. Therefore, the goal of this review and meta-analysis is to assess the evidence in support of IVFs in septic shock, focusing on the quantity of IVFs administered, and to determine if conservative fluid therapy is justifiable in septic patients. Like many other therapeutic areas in critical care, an approach to fluid administration that employs therapeutic minimization may be preferred for the avoidance of complications and optimization of patient outcomes.

\section{Methods}

We conducted an English language search of PubMed and Cochrane databases from January 1980 to December 2014 to find human trials of sepsis care bundles in adults (aged $\geq 18$ years) using these search terms: sepsis, septic shock, treatment, guidelines, protocols, GDT, and bundles (Figure 1). The studies that were included had to enroll septic patients, have a control (historical or concurrent), and record mortality rates. The included studies also had to provide targets for their usage of fluids as part of their sepsis intervention or sepsis bundle. Criteria for sepsis or septic shock in patients receiving bundled care had to be consistent with the American College of Chest Physicians and Society of Critical Care Medicine Consensus Conference definitions [17]. Both investigators independently reviewed the included studies by using a standardized data collection form. Discrepancies were resolved by discussion. The Scottish Intercollegiate Guidelines Network checklist for randomized, controlled trials [18] was used to evaluate the methodological quality of the identified studies included in this analysis. A double plus $(++)$ denotes studies very unlikely to have bias, plus $(+)$ studies where bias is unlikely, and minus (-) studies with high risk of bias [18]. 


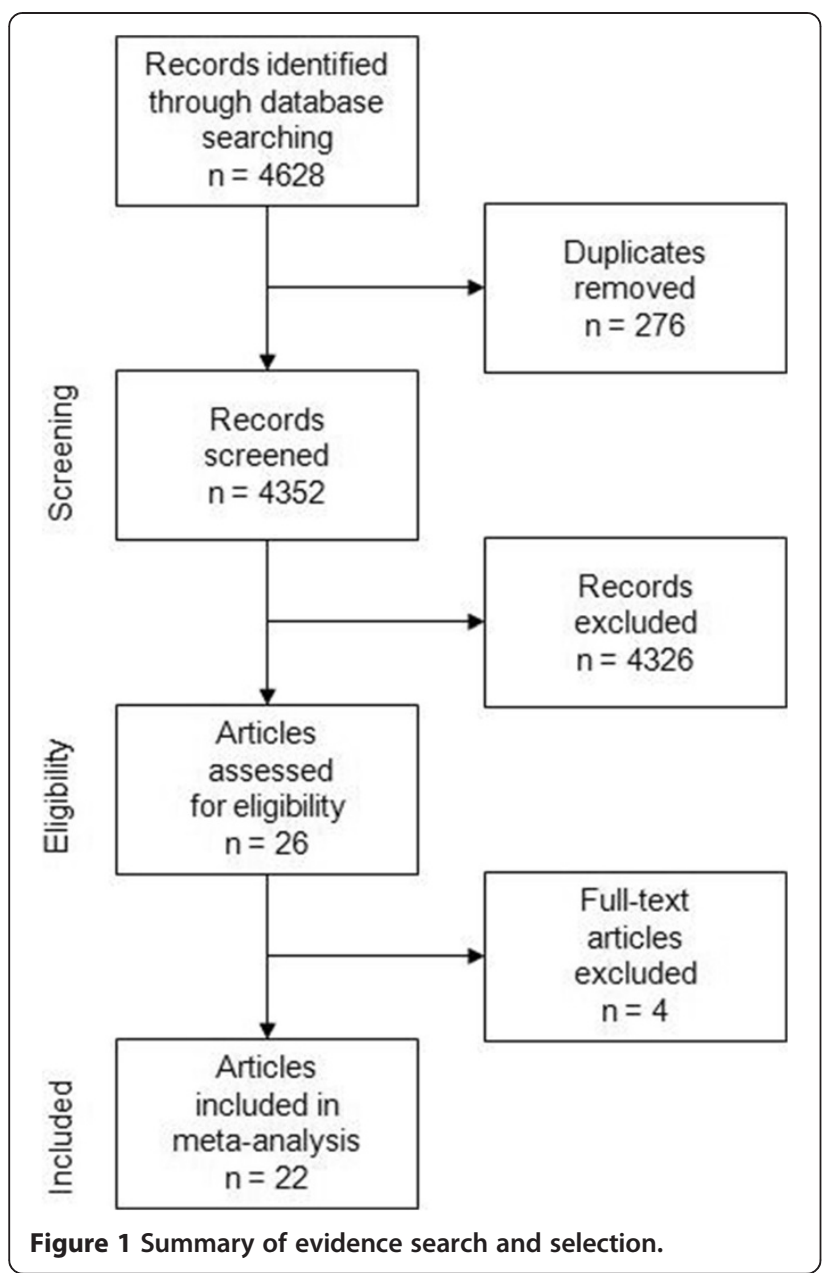

Survival was the outcome of interest and tabulated across studies. Conventional forest plots were prepared for survival. A statistical difference between groups was considered to occur if the pooled $95 \%$ confidence interval (CI) did not include 1 for the odds ratio (OR). An OR $<1$ favored bundled GDT when compared with a control group. Two-sided $P$-values were calculated. A random-effects model was chosen for all analyses. Statistical heterogeneity and inconsistency were assessed by using the $Q$ and $I^{2}$ tests, respectively $[19,20]$. When the $P$-value of the $Q$-test was $<0.10$, the $I^{2}$ was $>25 \%$, or both, heterogeneity and inconsistency were considered significant [19,21].

\section{Randomized controlled trials}

The authors of the Surviving Sepsis Campaign recommend the protocolized, quantitative resuscitation of patients with sepsis-induced tissue hypoperfusion (defined as hypotension persisting after initial fluid challenge or blood lactate concentration $\geq 4 \mathrm{mmol} / \mathrm{L}$ ) [1]. They recommend initiating this protocol as soon as hypoperfusion is recognized and it should not be delayed pending ICU admission. During the first 6 hours of resuscitation, the recommended resuscitation goals include all of the following: central venous pressure (CVP) 8 to $12 \mathrm{mmHg}$; mean arterial pressure $\geq 65 \mathrm{mmHg}$; urine output $\geq 0.5 \mathrm{ml} \mathrm{kg} \mathrm{h}^{-1}$; superior vena cava oxygen saturation $\left(\mathrm{ScvO}_{2}\right)$ or mixed venous oxygen saturation 70 or $65 \%$, respectively. The primary rationale for this recommendation comes from a randomized, controlled, single-center study demonstrating that early quantitative resuscitation improved survival for emergency department patients presenting with septic shock [2]. Resuscitation targeting the physiologic goals noted above for the initial 6-hour period was associated with a $15.9 \%$ absolute reduction in 28 -day mortality $(46.5 \%$ versus $30.5 \%, P=0.009$ ).

Bundled GDT was also evaluated in a multicenter trial of 314 patients with severe sepsis in eight Chinese centers [22]. This trial reported a $17.7 \%$ absolute reduction in 28 -day mortality $(42.5 \%$ versus $24.8 \%, P=0.001)$. A single-center randomized controlled study from Taiwan in 224 medical ICU patients using the protocol of Rivers and colleagues [2] also demonstrated a survival advantage with bundled GDT (hospital mortality, 46.3\% versus 28.4\%, $P=0.006$ ) [23]. Most recently, the multicenter ProCESS trial enrolled 1,341 patients into three treatment groups (protocol-based GDT, protocol-based standard therapy, usual care) [24]. No difference in 60-day mortality was observed between the three groups (protocol-based GDT versus usual care: $21.0 \%$ versus $18.9 \%, P=0.830$ ).

These four randomized trials included a total of 2,131 patients; 834 (39.1\%) in the bundled GDT arm and 851 (39.9\%) in the control arm (446 (20.9\%) were in the protocol-based standard therapy group of the ProCESS trial). All four studies used the same targeted goals for fluid administration and for the use of vasopressors. The reported total IVF administration for shock varied from 5.0 liters in the control arm of the Taiwanese study to 3.5 liters in the control arm of the Rivers study at 6 hours and 2.3 liters at 6 hours in the control arm of the ProCESS trial (Table 1). Bundled GDT was applied in the emergency department in two studies $[2,24]$ and the ICU in two studies [22,23]. Patients who were treated with bundled GDT did not achieve a significant reduction in mortality compared with those in the control arm (OR 0.609; 95\% CI 0.363 to 1.020; $P=0.059$; Figure 2). The trials were inconsistent and heterogeneous $\left(I^{2}=80 \%, P=0.002\right)$. With removal of the ProCESS trial, the remaining three trials were without heterogeneity and were consistent $\left(I^{2}=0 \%, P=0.915\right)$, demonstrating a significant reduction in mortality with GDT (OR 0.475; 95\% CI 0.353 to 0.639; $P<0.001$ ). However, these three trials combined had fewer patients enrolled compared to the ProCESS trial. 
Table 1 Randomized controlled trials of bundled goal-directed therapy

\begin{tabular}{|c|c|c|c|c|c|}
\hline \multirow[t]{2}{*}{ Study and country } & \multirow[t]{2}{*}{ Sign score } & \multirow[t]{2}{*}{ Goal-directed therapy (goals) } & & \multicolumn{2}{|c|}{ Time and fluid quantification (L) } \\
\hline & & & & Control & GDT \\
\hline \multirow[t]{2}{*}{ Rivers et al. 2001, USA [2] } & \multirow[t]{2}{*}{+} & \multirow{2}{*}{$\begin{array}{l}500 \mathrm{ml} \text { crystalloid bolus every } \\
30 \text { minutes (CVP 8-12 mmHg) }\end{array}$} & $6 \mathrm{~h}:$ & $3.5 \pm 2.4$ & $5.0 \pm 3.0$ \\
\hline & & & 7-72 h: & $10.6 \pm 6.2$ & $8.6 \pm 5.2$ \\
\hline Lin et al. 2006, Taiwan [23] & + & $\begin{array}{l}500 \mathrm{ml} \text { crystalloid bolus every } \\
30 \text { minutes (CVP 8-12 mmHg) }\end{array}$ & Total: & $5.0 \pm 2.9$ & $5.2 \pm 4.0$ \\
\hline $\begin{array}{l}\text { GDT Collaborative Group of Zhejiang } \\
\text { Province 2010, China [22] }\end{array}$ & - & $\begin{array}{l}500 \mathrm{ml} \text { crystalloid bolus every } \\
30 \text { minutes (CVP 8-12 mmHg) }\end{array}$ & & Quantified but not reported & \\
\hline ProCESS 2014, USA [24] & ++ & $\begin{array}{l}500 \mathrm{ml} \text { crystalloid bolus every } \\
30 \text { minutes (CVP 8-12 mmHg) }\end{array}$ & $6 \mathrm{~h}:$ & $2.3 \pm 1.9$ & $2.8 \pm 2.0$ \\
\hline
\end{tabular}

Double plus signs (++) indicate studies with very unlikely bias, a single plus sign (+) indicates studies with unlikely bias, and a minus sign (-) indicates studies with high risk of bias. CVP, central venous pressure; GDT, goal-directed therapy.

\section{Observational trials}

Eighteen observational trials of bundled GDT were identified [25-42] (Table 2). Seven of these trials were assessed in an earlier analysis demonstrating that a bundled care protocol for septic shock that included the elements of GDT was associated with a significant improvement in hospital survival [15]. Across the 18 studies, the effect of bundled care on survival was heterogeneous and inconsistent $\left(I^{2}=32 \%, P=0.091\right.$; Figure 3$)$. However, when the study by Ferrer and colleagues [33] was removed, the remaining 17 studies were without heterogeneity and were consistent $\left(I^{2}=0 \%, P=0.796\right)$. Overall, there was a statistically significant increase in the odds of surviving with bundled care compared with controls when all studies were examined (OR 0.580; 95\% CI 0.501 to 0.672; $P<0.0001)$. Statistical significance was maintained when the Ferrer study was removed from the analysis (OR $0.561 ; 95 \%$ CI 0.499 to $0.631 ; P<0.0001)$.

\begin{tabular}{|l|l|}
\hline \multicolumn{1}{|c|}{ Study name } & $\begin{array}{c}\text { Odds ratio } \\
\text { and 95\% } \mathbf{C l}\end{array}$ \\
Rivers et al, 2001 \\
Lin et al, 2006 \\
Zhejiang Province, 2010 \\
ProCESS, 2014
\end{tabular}

\section{Limitations of the bundled goal-directed therapy studies}

One of the proposed main limitations of the pivotal Rivers trial is the lack of generalizability of the study. For example, Ho and colleagues [43] examined 4,784 emergency department patients and found only $40(0.8 \%)$ were candidates for bundled GDT. Moreover, these investigators found patient mortality to be $26.0 \%$, much lower than the mortality observed in the control arm of the Rivers study, which was $46.5 \%$, and the control arm mortality in the other two older randomized trials of bundled GDT $[2,22,23,43]$. Variability in mortality was also observed in the 18 observational studies examined where the mortality of the control arms ranged from $15.5 \%$ to $67.6 \%$ [25-42]. Interestingly, the ProCESS trial had one of the lowest observed mortality rates in their control arm at $18.9 \%$. Other limitations of these trials include resuscitation protocol complexity, potential risks associated with elements of the protocol (especially the use of dobutamine and red blood cell transfusions), and financial and infrastructure implications necessary to carry out these protocols. For example, in the Rivers trial the bundled GDT patients had a dedicated investigator to ensure compliance with the study protocol and had central venous catheters placed to continuously assess $\mathrm{ScvO}_{2}$.

The observational studies of bundled GDT have a number of other important limitations, foremost being their lack of scientific rigor (Table 2). It is also important to note that the earlier meta-analysis of seven of these trials found that only time to antibiotic administration (in hours) between bundle and control patients was consistent between studies, whereas crystalloids, vasopressors, inotropes, packed red blood cell transfusion, corticosteroids, and drotrecogin alfa (activated) exhibited significant heterogeneity between the studies [15]. The overall importance of timely antibiotic therapy was further supported by the analysis of the Spanish study that examined 2,319 patients showing a reduction in mortality with bundled GDT [33]. In a subsequent analysis of 


\begin{tabular}{|c|c|c|c|c|c|}
\hline \multirow[t]{2}{*}{ Study and country } & \multirow[t]{2}{*}{ Sign score } & \multirow[t]{2}{*}{ Goal-directed therapy (goals) } & & \multicolumn{2}{|c|}{ Time and fluid quantification (L) ${ }^{a}$} \\
\hline & & & & Control & Bundled GDT \\
\hline Cardoso et al. 2010, Portugal [42] & $(-)$ & $\begin{array}{l}500 \mathrm{ml} \text { to } 1000 \mathrm{ml} \text { crystalloid bolus, or } 300 \mathrm{ml} \\
\text { to } 500 \mathrm{ml} \text { colloid bolus to achieve CVP } \geq 12 \mathrm{mmHg}\end{array}$ & & \multicolumn{2}{|c|}{ Quantified but not reported. } \\
\hline Castellanos-Ortega et al. 2010, Spain [35] & $(-)$ & $\begin{array}{l}500-1000 \mathrm{ml} \text { crystalloid bolus, additional fluid } \\
\text { to achieve CVP } \geq 8 \mathrm{mmHg}\end{array}$ & & \multicolumn{2}{|c|}{ Quantified but not reported. } \\
\hline \multirow[t]{2}{*}{ El Solh et al. 2008, USA [31] } & $(-)$ & $500 \mathrm{ml}$ crystalloid bolus, repeat until CVP $8-12 \mathrm{mmHg}$ & $6 \mathrm{~h}:$ & $2.5 \pm 1.0$ & $3.9 \pm 2.0$ \\
\hline & & & $24 \mathrm{~h}:$ & $3.2 \pm 1.3$ & $4.9 \pm 2.5$ \\
\hline Ferrer et al. 2008, Spain [33] & $(-)$ & $500 \mathrm{ml}$ crystalloid bolus, repeat until CVP $8-12 \mathrm{mmHg}$ & & \multicolumn{2}{|c|}{ Quantified but not reported } \\
\hline Gao et al. 2005, UK [36] & $(-)$ & Immediate fluid bolus of $0.5 \mathrm{~L}$ & & \multicolumn{2}{|c|}{ Quantified but not reported } \\
\hline Girardis et al. 2009, Italy [34] & $(-)$ & $\begin{array}{l}\text { Fluids targeting CVP }>6 \mathrm{mmHg} \text { or a global end-diastolic } \\
\text { volume by trans-pulmonary thermodilution }>700 \mathrm{ml} / \mathrm{m}^{2}\end{array}$ & & \multicolumn{2}{|c|}{ Quantified but not reported } \\
\hline Heppner et al. 2012, Germany [39] & $(-)$ & $500 \mathrm{ml}$ crystalloid bolus, repeat until CVP $8-12$ mmHg & & \multicolumn{2}{|c|}{ Quantified but not reported. } \\
\hline Jones et al. 2007, USA [30] & $(-)$ & $500 \mathrm{ml}$ crystalloid bolus, repeat until CVP $8-12 \mathrm{mmHg}$ & $6 \mathrm{h:}$ & $2.5 \pm 2.4$ & $4.7 \pm 1.8$ \\
\hline Kortgen et al. 2006, Germany [27] & $(-)$ & $\begin{array}{l}\text { CVP 8-12 } \mathrm{mmHg} \text { or intrathoracic blood volume } \\
\text { index } 850-1000 \mathrm{ml} / \mathrm{m}^{2}\end{array}$ & $6 \mathrm{~h}:$ & $2.8[1.8,3.8]$ & $2.5[1.6,3.9]$ \\
\hline \multirow[t]{2}{*}{ Lefrant et al. 2010, France [41] } & \multirow[t]{2}{*}{$(-)$} & \multirow[t]{2}{*}{$\geq 20 \mathrm{ml} / \mathrm{kg}$ crystalloids or colloids within 6 hours } & 6 h crystalloid: & $1.0[0.5,2.0]$ & $1.5[0.5,2.0]$ \\
\hline & & & 6 h colloid: & $0.5[0.5,1.0]$ & $1.0[0.5,1.1]$ \\
\hline Micek et al. 2006, USA [25] & $(-)$ & $500 \mathrm{ml}$ crystalloid bolus, repeat until CVP $8-12 \mathrm{mmHg}$ & In ED: & $2.8 \pm 1.6$ & $3.8 \pm 1.7$ \\
\hline Miller et al. 2013, USA [38] & $(-)$ & $500 \mathrm{ml}$ crystalloid bolus, repeat until CVP $8-12$ mmHg & & \multicolumn{2}{|c|}{ Quantified but not reported. } \\
\hline \multirow[t]{2}{*}{ Na et al. 2012, Asia [40] ${ }^{\mathrm{b}}$} & \multirow[t]{2}{*}{$(-)$} & \multirow[t]{2}{*}{ Fluid bolus to achieve CVP $>8 \mathrm{mmHg}$ by 6 hours } & In ED: & $1.5[1.0,2.5]$ & $1.5[0.9,2.7]$ \\
\hline & & & In ICU: & $7.8[5.2,11.6]$ & $5.6[3.3,9.2]$ \\
\hline \multirow[t]{2}{*}{ Nguyen et al. 2007, USA [29] } & \multirow[t]{2}{*}{$(-)$} & \multirow[t]{2}{*}{$\mathrm{CVP} \geq 8 \mathrm{mmHg}$} & In ED: & $2.8 \pm 1.5$ & $2.8 \pm 2.1$ \\
\hline & & & $72 \mathrm{~h}:$ & $7.8 \pm 5.2$ & $7.9 \pm 6.1$ \\
\hline Pestaña et al. 2010, Spain [37] & $(-)$ & $\begin{array}{l}\text { Crystalloid within } 6 \text { hours to achieve CVP } \geq 8 \mathrm{mmHg} \\
\text { or global end-diastolic volume index } \geq 680 \mathrm{ml} / \mathrm{m}^{2}\end{array}$ & & \multicolumn{2}{|c|}{ Quantified but not reported. } \\
\hline Sebat et al. 2005, USA [32] & $(-)$ & $\begin{array}{l}1000 \mathrm{ml} \text { crystalloid in ED, } 600 \mathrm{ml} \text { increments per } \\
\text { MAP \& UO protocol }\end{array}$ & & Quantified bu & orted. \\
\hline \multirow[t]{2}{*}{ Shapiro et al. 2006, USA [28] } & \multirow[t]{2}{*}{$(-)$} & \multirow[t]{2}{*}{$500 \mathrm{ml}$ crystalloid bolus, repeat until CVP $8-12 \mathrm{mmHg}$} & $6 \mathrm{~h}:$ & $2.9 \pm 1.8$ & $4.1 \pm 2.6$ \\
\hline & & & $24 \mathrm{~h}:$ & $6.5 \pm 4.5$ & $7.6 \pm 3.9$ \\
\hline \multirow[t]{3}{*}{ Trzeciak et al. 2006, USA [26] } & \multirow[t]{3}{*}{$(-)$} & \multirow[t]{3}{*}{ 250-1000 ml crystalloid bolus until CVP $\geq 8$ mmHg } & ED: & $3.5 \pm 2.3$ & $5.7 \pm 3.0$ \\
\hline & & & ICU 24 h: & $5.5 \pm 4.9$ & $2.8 \pm 1.7$ \\
\hline & & & ED and ICU 24 h: & $9.1 \pm 5.1$ & $7.9 \pm 3.4$ \\
\hline
\end{tabular}

Double plus signs (++) indicate studies with very unlikely bias, a plus sign (+) indicates studies with unlikely bias, and a minus sign (-) indicates studies with high risk of bias. ${ }^{2}$ Values expressed as mean \pm standard

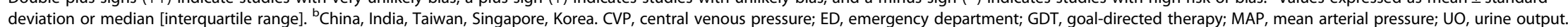




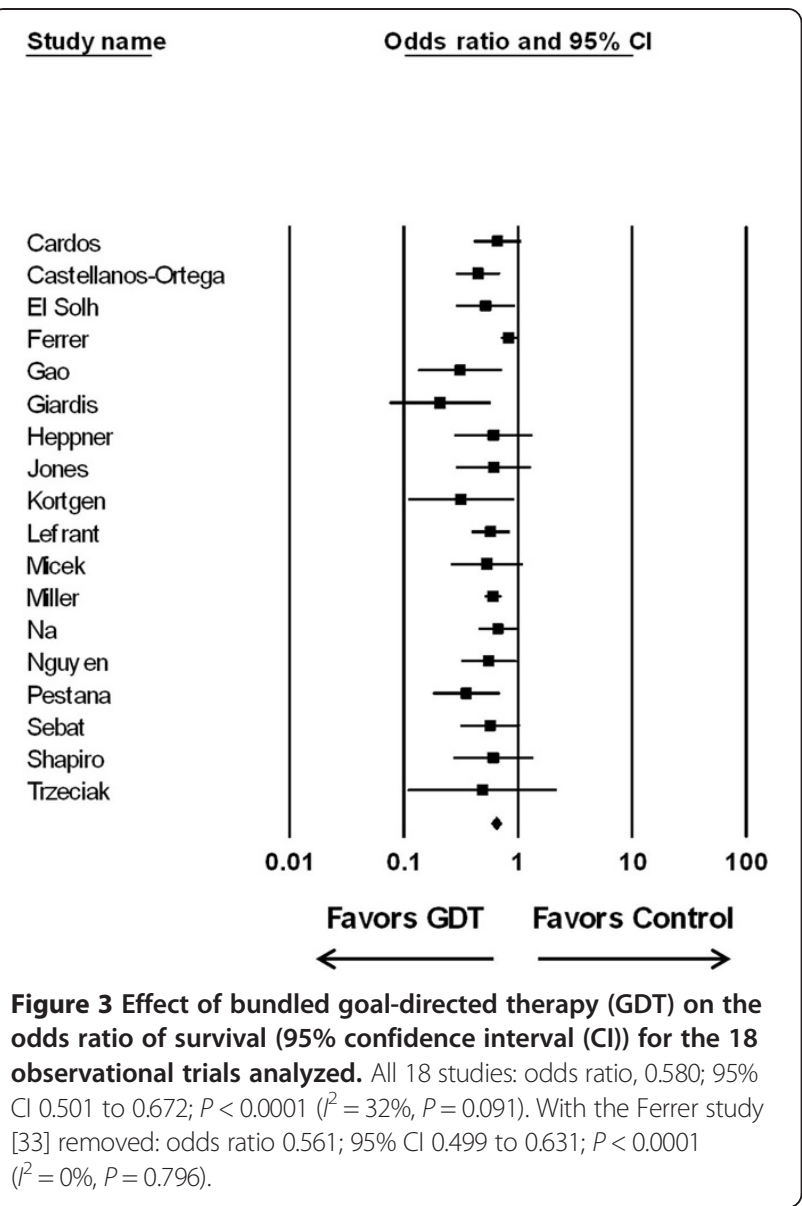

their data, the Spanish investigators reported on compliance with four therapeutic goals and four treatments employed in their bundle [44]. Only timely administration of antibiotics and drotrecogin alfa (activated) for multiorgan failure were associated with significantly lower mortality [44].

Another important limitation of both the randomized trials and the observational studies examining bundled GDT is that multiple interventions occurred that could potentially influence patient outcome. This is supported by the observation that statistical differences in the use of vasopressors, red blood cell transfusions, corticosteroids, and timely administration of antibiotics existed between study arms when the trials reporting specific interventions were combined for analysis (Table 3). Moreover, across the 12 studies reporting on IVF administration, most showed greater fluids administered to patients receiving bundled GDT (median (interquartile range): $3,875 \mathrm{ml}$ $(2,638 \mathrm{ml}, 4,901 \mathrm{ml})$ versus $2,779 \mathrm{ml}(2,332 \mathrm{ml}, 3,342 \mathrm{ml})$; $P=0.143$ ) (Tables 1 and 2). However, the studies were inconsistent and significant heterogeneity existed between studies for the difference in IVFs administered by treatment group $\left(I^{2}=90 \%, P<0.001\right)$ (Figure 4). Removal of any one study failed to significantly reduce heterogeneity ( $I^{2}$ remained $87 \%$ to $91 \%$, with $P<0.001$ ).

For completeness, one additional observational study was identified but not included in our analysis due to its makeup. This was a multicenter quality improvement study conducted in the United States, Europe, and South America utilizing a multifaceted intervention to facilitate compliance with selected guideline recommendations for the management of severe sepsis [45]. This intervention included the use of a CVP greater than $8 \mathrm{mmHg}$ to target fluid administration. Data on 15,022 patients at 165 hospitals were included in the analysis. Compliance with the initial 6-hour bundle targets increased linearly from 10.9\% of subjects in the first quarter to $31.3 \%$ by the end of 2 years of the quality improvement campaign. This was associated with a significant reduction in mortality over the same time period $(37.0 \%$ in the first quarter in the campaign to $30.8 \%$ by 2 years, $P=0.001$ ). After adjustment for baseline characteristics, administration of broad-spectrum antibiotics, obtaining blood cultures before antibiotic initiation, administration of drotrecogin alfa (activated) in the first 24 hours, achieving plateau pressure control, and maintaining blood glucose control were all associated with lower hospital mortality. In those with septic shock, there was no association between mortality and the ability to achieve a CVP $\geq 8 \mathrm{mmHg}$ or demonstration of $\mathrm{ScvO}_{2} \geq 70 \%$ [45].

The limitations of the available clinical studies of bundled GDT, to include the inconsistent results regarding IVF administration, have served as the major impetus for the conduct of three multicenter trials examining the elements of GDT (ARISE in Australasia, ProMISe in the United Kingdom, and ProCESS in the United States) $[24,43,46]$. These trials have similar structures, interventions, and patient entry criteria that will allow the trial investigators to collaboratively conduct a prospective individual patient data meta-analysis, using the raw data from each trial [46]. With over 4,000 subjects combined, these trials are powered to find smaller effects on outcome and to better explore subgroups. The ProCESS trial has already been published and showed that protocolized GDT did not reduce mortality compared with usual care [24]. However, patients in the usual care arm received significantly less IVF at 6 hours and had a numerically lower mortality compared to the protocolized GDT arm.

\section{Conclusion}

Clinicians caring for critically ill patients must always weigh the benefits and risks of administered therapies to include the use of IVFs. Our meta-analysis supports the findings of an earlier analysis [15] demonstrating that IVF volume was not consistently altered by the use of 
Table 3 Comparison of specific interventions employed in trials of bundled goal-directed therapy

\begin{tabular}{|c|c|c|c|c|c|c|c|c|c|c|c|c|c|c|}
\hline \multirow[b]{2}{*}{ Study } & \multicolumn{2}{|c|}{ Vasopressors } & \multicolumn{2}{|l|}{ Inotropes } & \multicolumn{2}{|l|}{ PRBC } & \multicolumn{2}{|c|}{ Corticosteroids } & \multicolumn{2}{|l|}{ rhAPC } & \multicolumn{2}{|c|}{ Appropriate antibiotics } & \multicolumn{2}{|c|}{ Timely antibiotics } \\
\hline & Control & $\begin{array}{l}\text { Bundled } \\
\text { care }\end{array}$ & Control & $\begin{array}{l}\text { Bundled } \\
\text { care }\end{array}$ & Control & $\begin{array}{l}\text { Bundled } \\
\text { care }\end{array}$ & Control & $\begin{array}{l}\text { Bundled } \\
\text { care }\end{array}$ & Control & Bundled care & Control & $\begin{array}{l}\text { Bundled } \\
\text { care }\end{array}$ & Control & $\begin{array}{l}\text { Bundled } \\
\text { care }\end{array}$ \\
\hline ProCESS [24] & $201 / 456$ & $241 / 439$ & $4 / 456$ & $35 / 439$ & $34 / 456$ & $63 / 439$ & $37 / 456$ & $54 / 439$ & $0 / 456$ & $1 / 439$ & $442 / 456$ & $428 / 439$ & NA & NA \\
\hline Rivers et al. [2] & $40 / 133$ & $36 / 130$ & $1 / 133$ & $18 / 130$ & $25 / 133$ & $83 / 130$ & NA & NA & NA & NA & $125 / 133$ & $126 / 130$ & $123 / 133$ & $112 / 130$ \\
\hline Lin et al. [23] & $81 / 116$ & $80 / 108$ & $16 / 116$ & $13 / 108$ & $43 / 116$ & $39 / 108$ & $25 / 116$ & $32 / 108$ & NA & NA & $107 / 116$ & $102 / 108$ & NA & NA \\
\hline El Solh et al. [31] & NA & NA & NA & NA & $11 / 87$ & $12 / 87$ & $14 / 87$ & $83 / 87$ & $2 / 87$ & $11 / 87$ & $73 / 87$ & $84 / 87$ & $79 / 87$ & $83 / 87$ \\
\hline Ferrer et al. [33] & $329 / 854$ & $630 / 1,465$ & NA & NA & NA & NA & $311 / 854$ & $611 / 1,465$ & $51 / 854$ & $74 / 1,465$ & $568 / 854$ & $1,009 / 1,465$ & NA & NA \\
\hline Jones et al. [30] & $27 / 79$ & $53 / 77$ & $1 / 79$ & $2 / 77$ & $1 / 79$ & $4 / 77$ & $5 / 79$ & $31 / 77$ & $3 / 79$ & $3 / 77$ & NA & NA & NA & NA \\
\hline Kortgen et al. [27] & NA & NA & $0 / 30$ & $6 / 30$ & $5 / 30$ & $5 / 30$ & $13 / 30$ & $30 / 30$ & $0 / 30$ & $7 / 30$ & $28 / 30$ & $28 / 30$ & $30 / 30$ & $30 / 30$ \\
\hline Lefrant et al. [41] & NA & NA & $40 / 230$ & $20 / 215$ & $24 / 230$ & $34 / 215$ & $91 / 230$ & $122 / 215$ & $0 / 230$ & $4 / 215$ & NA & NA & $141 / 230$ & $145 / 215$ \\
\hline Micek et al. [25] & $60 / 60$ & $43 / 60$ & NA & NA & $4 / 60$ & $12 / 60$ & $30 / 60$ & $13 / 60$ & $7 / 60$ & $2 / 60$ & $43 / 60$ & $52 / 60$ & $36 / 60$ & $52 / 60$ \\
\hline Na et al. [40] & $171 / 364$ & 135/192 & $144 / 364$ & 78/192 & $17 / 364$ & $4 / 192$ & NA & NA & NA & NA & NA & NA & NA & NA \\
\hline Nguyen et al. [29] & $39 / 77$ & $111 / 253$ & $18 / 77$ & $67 / 253$ & $11 / 77$ & $32 / 253$ & $23 / 77$ & $41 / 253$ & $6 / 77$ & $4 / 253$ & NA & NA & $77 / 77$ & $227 / 253$ \\
\hline Shapiro et al. [28] & $23 / 51$ & $63 / 79$ & $1 / 51$ & $6 / 79$ & $3 / 51$ & $8 / 79$ & $12 / 51$ & $23 / 79$ & $0 / 51$ & $3 / 79$ & $45 / 51$ & 77/79 & $48 / 51$ & $78 / 79$ \\
\hline Trezeciak et al. [26] & $7 / 16$ & $13 / 22$ & $0 / 16$ & $2 / 22$ & $0 / 16$ & $3 / 22$ & $5 / 16$ & $8 / 22$ & $2 / 16$ & $7 / 22$ & NA & NA & NA & NA \\
\hline Totals & $\begin{array}{l}978 / 2206 \\
(44.3)\end{array}$ & $\begin{array}{l}1,405 / 2,825 \\
(49.7)\end{array}$ & $\begin{array}{l}225 / 1,552 \\
(14.5)\end{array}$ & $\begin{array}{l}247 / 1,545 \\
(16.0)\end{array}$ & $\begin{array}{l}178 / 1,699 \\
(10.5)\end{array}$ & $\begin{array}{l}299 / 1,692 \\
(17.7)\end{array}$ & $\begin{array}{l}566 / 2,056 \\
(27.7)\end{array}$ & $\begin{array}{l}1,048 / 2,835 \\
(37.0)\end{array}$ & $\begin{array}{l}71 / 1940 \\
(3.7)\end{array}$ & $\begin{array}{l}116 / 2,727 \\
(4.3)\end{array}$ & $\begin{array}{l}1,431 / 1,787 \\
(80.1)\end{array}$ & $\begin{array}{l}1,906 / 2,398 \\
(79.5)\end{array}$ & $\begin{array}{l}534 / 668 \\
(79.9)\end{array}$ & $\begin{array}{l}727 / 854 \\
(85.1)\end{array}$ \\
\hline$P$-values ${ }^{a}$ & $<0.001$ & & 0.249 & & $<0.001$ & & $<0.001$ & & 0.308 & & 0.636 & & 0.008 & \\
\hline
\end{tabular}

${ }^{\mathrm{a}} \mathrm{P}$-values for comparison between control and bundled care groups for each intervention. NA, not available; PRBC, packed red blood cells; rhAPC, recombinant human activated protein C. 


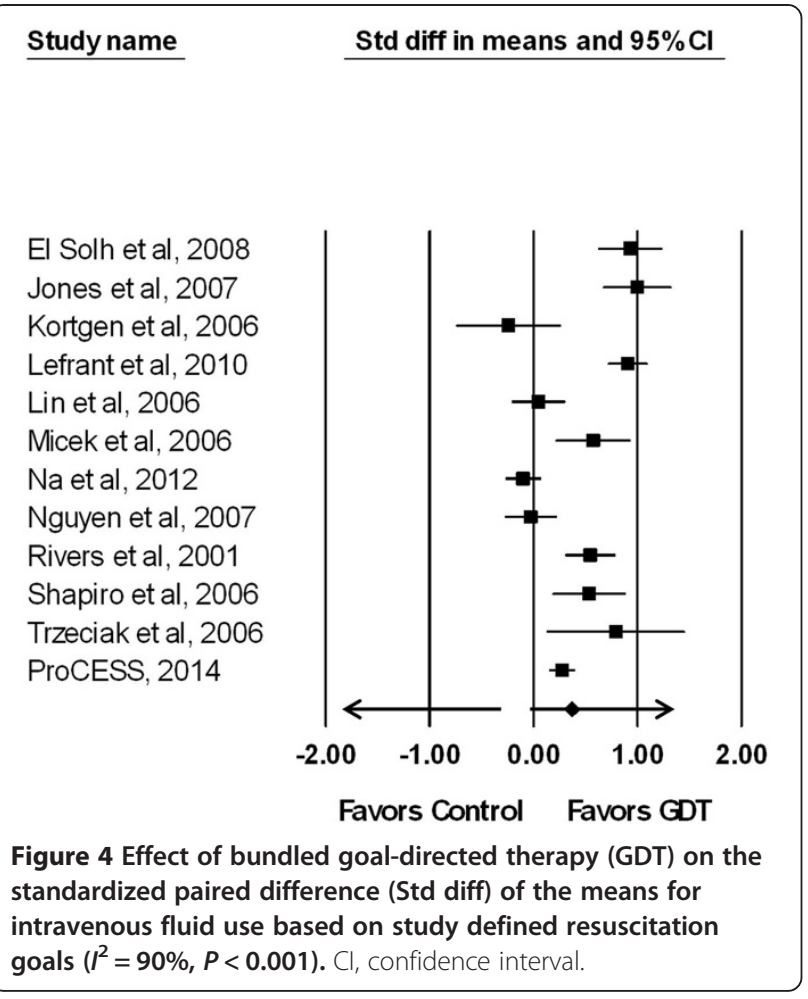

GDT bundles, and thus firm recommendations regarding their quantitative use cannot be made. Clinicians should at least be aware of the potential for harm due to the excessive administration of IVFs to patients with septic shock.

\section{Abbreviations \\ Cl: Confidence interval; CVP: Central venous pressure; GDT: Goal-directed therapy; IVF: Intravenous fluid; OR: Odds ratio; $\mathrm{SCVO}_{2}$ : Superior vena cava oxygen saturation.}

\section{Competing interests}

MHK's effort was supported by the Barnes-Jewish Hospital Foundation. The authors have no conflicts or competing interests to report in relation to this manuscript.

Published online: 29 August 2014

\section{References}

1. Dellinger RP, Levy MM, Rhodes A, Annane D, Gerlach H, Opal SM, Sevransky JE, Sprung CL, Douglas IS, Jaeschke R, Osborn TM, Nunnally ME, Townsend SR, Reinhart K, Kleinpell RM, Angus DC, Deutschman CS, Machado FR, Rubenfeld GD, Webb SA, Beale RJ, Vincent JL, Moreno R, Surviving Sepsis Campaign Guidelines Committee including the Pediatric Subgroup: Surviving Sepsis Campaign: international guidelines for management of severe sepsis and septic shock: 2012. Crit Care Med 2013, 41:580-637.

2. Rivers E, Nguyen B, Havstad S, Ressler J, Muzzin A, Knoblich B, Peterson E, Tomlanovich M, Early Goal-Directed Therapy Collaborative Group: Early goal-directed therapy in the treatment of severe sepsis and septic shock. N Engl J Med 2001, 345:1368-1377.

3. Carlet J, Jarlier V, Harbarth S, Voss A, Goossens H, Pittet D: Participants of the $3^{\text {rd }}$ World Healthcare-Associated Infections Forum: Ready for a world without antibiotics? The Pensières Antibiotic Resistance Call to Action Antimicrobial Resistance and Infection Control. Antimicrob Resist Infect Control 2012, 1:11.
4. Spellberg B, Bartlett JG, Gilbert DN: The future of antibiotics and resistance. N Engl J Med 2013, 368:299-302.

5. Arroliga AC, Thompson BT, Ancukiewicz M, Gonzales JP, Guntupalli KK, Park PK, Wiedemann HP, Anzueto A, Acute Respiratory Distress Syndrome Network: Use of sedatives, opioids, and neuromuscular blocking agents in patients with acute lung injury and acute respiratory distress syndrome. Crit Care Med 2008, 36:1083-1088.

6. Mehta S, Burry L, Fischer S, Martinez-Motta JC, Hallett D, Bowman D, Wong C, Meade MO, Stewart TE, Cook DJ, Canadian Critical Care Trials Group: Canadian survey of the use of sedatives, analgesics, and neuromuscular blocking agents in critically ill patients. Crit Care Med 2006, 34:374-380.

7. Amato MB, Barbas CS, Medeiros DM, Magaldi RB, Schettino GP, Lorenzi-Filho G, Kairalla RA, Deheinzelin D, Munoz C, Oliveira R, Takagaki TY, Carvalho CR: Effect of a protective-ventilation strategy on mortality in the acute respiratory distress syndrome. N Engl J Med 1998, 338:347-354.

8. The Acute Respiratory Distress Syndrome Network: Ventilation with lower tidal volumes as compared with traditional tidal volumes for acute lung injury and the acute respiratory distress syndrome. N Engl J Med 2000, 342:1301-1308.

9. Hébert PC, Wells G, Blajchman MA, Marshall J, Martin C, Pagliarello G, Tweeddale M, Schweitzer I, Yetisir E: A multicenter, randomized, controlled clinical trial of transfusion requirements in critical care. Transfusion Requirements in Critical Care Investigators, Canadian Critical Care Trials Group. N Engl J Med 1999, 340:409-417.

10. Finfer S, Wernerman J, Preiser JC, Cass T, Desaive T, Hovorka R, Joseph Jl, Kosiborod M, Krinsley J, Mackenzie I, Mesotten D, Schultz MJ, Scott MG, Slingerland R, Van den Berghe G, Van Herpe T: Clinical review: Consensus recommendations on measurement of blood glucose and reporting glycemic control in critically ill adults. Crit Care 2013, 17:229.

11. Balogh Z, Moore FA, Moore EE, Biffl WL: Secondary abdominal compartment syndrome: a potential threat for all trauma clinicians. Injury 2007, 38:272-279.

12. Coats TJ, Brazil E, Heron M, MacCallum PK: Impairment of coagulation by commonly used resuscitation fluids in human volunteers. Emerg Med $J$ 2006, 23:846-849.

13. Krausz MM: Initial resuscitation of hemorrhagic shock. World J Emerg Surg 2006, 1:14.

14. Heart N, Lung, and Blood Institute Acute Respiratory Distress Syndrome (ARDS) Clinical Trials Network, Wiedemann HP, Wheeler AP, Bernard GR, Thompson BT, Hayden D, DeBoisblanc B, Connors AF Jr, Hite RD, Harabin AL: Comparison of two fluid-management strategies in acute lung injury. N Engl J Med 2006, 354:2564-2575.

15. Barochia AV, Cui X, Vitberg D, Suffredini AF, O'Grady NP, Banks SM, Minneci P, Kern SJ, Danner RL, Natanson C, Eichacker PQ: Bundled care for septic shock: an analysis of clinical trials. Crit Care Med 2010, 38:668-678.

16. Angus DC, van der Poll T: Severe sepsis and septic shock. N Engl J Med 2013, 369:840-851

17. Bone RC, Balk RA, Cerra FB, Dellinger RP, Fein AM, Knaus WA, Schein RM, Sibbald WJ: Definitions for sepsis and organ failure and guidelines for the use of innovative therapies in sepsis, The ACCP/SCCM Consensus Conference Committee. American College of Chest Physicians/Society of Critical Care Medicine. Chest 1992, 101:1644-1655.

18. Scottish Intercollegiate Guidelines Network (SIGN) 50: A Guideline Developer's Handbook. http://www.sign.ac.uk/guidelines/fulltext/50/index.html.

19. Higgins JPT, Thompson SG: Quantifying heterogeneity in a meta-analysis. Stat Med 2002, 21:1539-1558.

20. Higgins JPT, Thompson SG, Deeks JJ, Altman DG: Measuring inconsistency in meta-analyses. Br Med J 2003, 327:557-560.

21. Deeks JJ, Higgins JPT, Altman DG: Analysing data undertaking meta-analyses. In Cochrane Handbook for Systematic Reviews of Interventions. Version 5.0.1 Edited by Higgins JPT, Green S. Sussex: The Cochrane Collaboration; 2008:244-265

22. Early Goal-Directed Therapy Collaborative Group of Zhejiang Province: The effect of early goal-directed therapy on treatment of critical patients with severe sepsis/septic shock: a multi-center, prospective, randomized, controlled study. Zhongquo Wei Zhong Bing Ji Jiu Yi Xue 2010, 22:331-334.

23. Lin SM, Huang CD, Lin HC, Liu CY, Wang CH, Kuo HP: A modified goal-directed protocol improves clinical outcomes in intensive care unit patients with septic shock: a randomized controlled trial. Shock 2006, 26:551-557.

24. The ProCESS Investigators: A randomized trial of protocol-based care for early septic shock. N Engl J Med 2014, 370:1683-1693. 
25. Micek ST, Roubinian N, Heuring T, Bode M, Williams J, Harrison C, Murphy T, Prentice D, Ruoff BE, Kollef MH: Before-after study of a standardized hospital order set for the management of septic shock. Crit Care Med 2006, 34:2707-2713.

26. Trzeciak S, Dellinger RP, Abate NL, Cowan RM, Stauss M, Kilgannon JH, Zanotti S, Parrillo JE: Translating research to clinical practice: a 1-year experience with implementing early goal-directed therapy for septic shock in the emergency department. Chest 2006, 129:225-232.

27. Kortgen A, Niederprum P, Bauer M: Implementation of an evidence-based "standard operating procedure" and outcome in septic shock. Crit Care Med 2006, 34:943-949.

28. Shapiro NI, Howell MD, Talmor D, Lahey D, Ngo L, Buras J, Wolfe RE, Weiss JW, Lisbon A: Implementation and outcomes of the Multiple Urgent Sepsis Therapies (MUST) protocol. Crit Care Med 2006, 34:1025-1032.

29. Nguyen HB, Corbett SW, Steele R, Banta J, Clark RT, Hayes SR, Edwards J, Cho TW, Wittlake WA: Implementation of a bundle of quality indicators for the early management of severe sepsis and septic shock is associated with decreased mortality. Crit Care Med 2007, 35:1105-1112.

30. Jones AE, Focht A, Horton JM, Kline JA: Prospective external validation of the clinical effectiveness of an emergency department-based early goal-directed therapy protocol for severe sepsis and septic shock. Chest 2007, 132:425-432.

31. El Solh AA, Akinnusi ME, Alsawalha LN, Pineda LA: Outcome of septic shock in older adults after implementation of the sepsis "bundle". J Am Geriatr Soc 2008, 56:272-278.

32. Sebat F, Johnson D, Musthafa AA, Watnik M, Moore S, Henry K, Saari M: A multidisciplinary community hospital program for early and rapid resuscitation of shock in nontrauma patients. Chest 2005, 127:1729-1743.

33. Ferrer R, Artigas A, Levy MM, Blanco J, González-Díaz G, Garnacho-Montero J, Ibáñez J, Palencia E, Quintana M, De la Torre-Prados MV, Edusepsis Study Group: Improvement in process of care and outcome after a multicenter severe sepsis educational program in Spain. JAMA 2008, 299:2294-2303.

34. Girardis M, Rinaldi L, Donno L, Marietta M, Codeluppi M, Marchegiano P, Venturelli C, Sopravvivere alla Sepsi Group of the Modena-University Hospital: Effects on management and outcome of severe sepsis and septic shock patients admitted to the intensive care unit after implementation of a sepsis program: a pilot study. Crit Care 2009, 13:R143.

35. Castellanos-Ortega A, Suberviola B, García-Astudillo LA, Holanda MS, Ortiz F, Llorca J, Delgado-Rodríguez M: Impact of the Surviving Sepsis Campaign protocols on hospital length of stay and mortality in septic shock patients: results of a three-year follow-up quasi-experimental study. Crit Care Med 2010, 38:1036-1043.

36. Gao F, Melody T, Daniels DF, Giles S, Fox S: The impact of compliance with 6-hour and 24-hour sepsis bundles on hospital mortality in patients with severe sepsis: a prospective observational study. Crit Care 2005, 9:R764-R770.

37. Pestaña D, Espinosa E, Sangüesa-Molina JR, Ramos R, Pérez-Fernández E, Duque M, Martínez-Casanova E, REASEP Sepsis Study Group: Compliance with a sepsis bundle and its effect on intensive care unit mortality in surgical septic shock patients. J Trauma 2010, 69:1282-1287.

38. Miller RR 3rd, Dong L, Nelson NC, Brown SM, Kuttler KG, Probst DR, Allen TL, Clemmer TP, Intermountain Healthcare Intensive Medicine Clinical Program: Multicenter implementation of a severe sepsis and septic shock treatment bundle. Am J Respir Crit Care Med 2013, 188:77-82.

39. Heppner HJ, Singler K, Kwetkat A, Popp S, Esslinger AS, Bahrmann P, Kaiser M, Bertsch T, Sieber CC, Christ M: Do clinical guidelines improve management of sepsis in critically ill elderly patients? A before-and-after study of the implementation of a sepsis protocol. Wien Klin Wochenschr 2012, 124:692-698.

40. Na S, Kuan WS, Mahadevan M, Li CH, Shrikhande P, Ray S, Batech M, Nguyen HB, ATLAS Investigators: Implementation of early goal-directed therapy and the surviving sepsis campaign resuscitation bundle in Asia. Int J Qual Health Care 2012, 24:452-462.

41. Lefrant JY, Muller $L$, Raillard A, Jung B, Beaudroit L, Favier L, Masson B, Dingemans G, Thévenot F, Selcer D, Jonquet O, Capdevila X, Fabbro-Peray P, Jaber S, Sepsi d'Oc study Group in the AzuRéa Group: Reduction of the severe sepsis or septic shock associated mortality by reinforcement of the recommendations bundle: a multicenter study. Ann Fr Anesth Reanim 2010, 29:621-628.

42. Cardoso T, Carneiro AH, Ribeiro O, Teixeira-Pinto A, Costa-Pereira A: Reducing mortality in severe sepsis with the implementation of a core 6-hour bundle: results from the Portuguese community-acquired sepsis study (SACiUCI study). Crit Care 2010, 14:R83.

43. Ho BC, Bellomo R, McGain F, Jones D, Naka T, Wan L, Braitberg G: The incidence and outcome of septic shock patients in the absence of early-goal directed therapy. Crit Care 2006, 10:R80.

44. Ferrer $R$, Artigas A, Suarez D, Palencia E, Levy MM, Arenzana A, Pérez XL, Sirvent JM, Edusepsis Study Group: Effectiveness of treatments for severe sepsis: a prospective, multicenter, observational study. Am J Respir Crit Care Med 2009, 180:861-866.

45. Levy MM, Dellinger RP, Townsend SR, Linde-Zwirble WT, Marshall JC, Bion J, Schorr C, Artigas A, Ramsay G, Beale R, Parker MM, Gerlach H, Reinhart K, Silva E, Harvey M, Regan S, Angus DC, Surviving Sepsis Campaign: The Surviving Sepsis Campaign: results of an international guideline-based performance improvement program targeting severe sepsis. Crit Care Med 2010, 38:367-374

46. ProCESS/ARISE/ProMISe Methodology Writing Committee, Huang DT, Angus DC, Barnato A, Gunn SR, Kellum JA, Stapleton DK, Weissfeld LA, Yealy DM, Peake SL, Delaney A, Bellomo R, Cameron P, Higgins A, Holdgate A, Howe B, Webb SA, Williams P, Osborn TM, Mouncey PR, Harrison DA, Harvey SE, Rowan KM: Harmonizing international trials of early goal-directed resuscitation for severe sepsis and septic shock: methodology of ProCESS, ARISE, and ProMISe. Intensive Care Med 2013, 39:1760-1775.

doi:10.1186/s13054-014-0481-5

Cite this article as: Chen and Kollef: Conservative fluid therapy in septic shock: an example of targeted therapeutic minimization. Critical Care 2014 18:481. 